\title{
ALTERNATIVE DRIVE SYSTEMS AND ENVIRONMENTALY FRIENDLY PUBLIC PASSENGERS TRANSPORT
}

UDC: $656.132: 629.4 .016 .2$

Review paper

https://doi.org/10.18485/aeletters.2018.3.3.4

\section{Saša Milojević ${ }^{1}$, Tomas Skrucany ${ }^{2}$, Hranislav Milošević ${ }^{3}$, Darko Stanojević ${ }^{4}$, Mladen Pantić ${ }^{5}$, Blaža Stojanović}

${ }^{1}$ University of Kragujevac, Faculty of Engineering, Department for Motor Vehicles and IC Engines, Serbia

${ }^{2}$ University of Zilina, Faculty of Operation and Economics of Transport and Communications, Slovakia

${ }^{3}$ University in Kosovska Mitrovica, Faculty of Mathematics and Sciences Kosovska Mitrovica, Serbia

${ }^{4}$ Belgrade University, Faculty of Mechanical Engineering, Department for Motor Vehicles, Serbia

${ }^{5}$ State University of Novi Pazar, Department of Technical Sciences, Serbia

${ }^{6}$ University of Kragujevac, Faculty of Engineering, Department for Mechanical Construction and Mechanization, Serbia

\begin{abstract}
:
City transport causes the biggest part of road transport emissions. Besides, by engaging mainly fossil fuels in the city transport, we are responsible for air pollution in urban areas. On the other hand, passengers transport (private and public, individual and mass) may contribute substantially to reduce the negative impact on the environment by application of alternative fuels and declining of the use of fossil fuels. The main alternative fuels for drive systems in transport are the following: electricity, hydrogen, and biofuels. Synthetic fuels are option as a technology. Some of them are very effective but too expensive technologies. Another way is introduction of flexible transport (from door to door, on demand, etc.) which application enables to decrease the number of cars in urban centers to avoid congestions and the negative impact on the environment. This paper points out that public transport has a special role in the process of decreasing fossil fuel dependence, and the necessity for rapid alternative technology implementation, as well as development of the public transport system itself. Proposed is the introduction of public passenger transport from door to door that offers a comfort comparable to personal cars (specifically for handicapped persons) and helps to lowering congestions on the roads.
\end{abstract}

\section{ARTICLE HISTORY}

Received 14.07.2018.

Accepted 02.08.2018.

Available 30.09.2018.

\section{KEYWORDS}

alternative fuels, buses, drive systems, ecology, passengers transport

\section{INTRODUCTION}

The nature of mobility has changed over time, as well as travel manner have changed and people are traveling long distances. Motorized means are replacing the non-motorized, with a preference to means of transport such as the automobile. The use of motorized means (cars, motorcycles and buses) has pushed energy demand, especially for fossil fuels, to very high level. Today, fossil fuels are dominant in transport sector, where intensified energy consumption.

On the other hand people in villages, suburbs, highlands, as well as people work in isolated plants and restricted areas, far from the traffic lines are forced to use their cars, contributing to the congestion, fossil fuel wasting and pollution in urban areas.

Generally, the reasons why people use cars for city transport are numerous: uncomfortable public transport, habitation places not covered by public 
transport, inaccessibility (persons with children, elderly people, handicapped, etc.), inflexibility (moving out of routine), bad habit created by cheap fuel and used vehicles, and so on.

City traffic and traffic flow have the greatest impact on the exhaust emission and air pollution, specifically in the street canyons, zones of city centers etc. [1]. Design of road also has an impact on the cost of driving, safety and passenger comfort [2]. Moreover, in area of city traffic it can contribute substantially in declining of exhaust emission, by application of various methods. Some of them may be very effective and not too expensive like for instance:

$\checkmark$ To switch on alternative fuels, biofuels, natural gas and hydrogen/electricity as clean driving energy, with parallel introduction of flexible transport which enables to decrease the number of vehicles in urban centers to avoid congestion [3-10];

$\checkmark$ Further optimization of internal combustion (IC) engines by lowering internal friction and mechanical losses, in order to reduce fuel consumption and exhaust emissions [11-19]; and

$\checkmark$ Reliability characteristics, the proper approach and model that supports decisionmaking process in planning and controlling of spare parts in vehicles maintenance system [20].

If the number of personal cars were decreased significantly in city transport, tremendous results would be achieved concerning fuel economy, environmental protection and social life. As a contribution to above mention serve the next facts: enormous fuel prices on the market and restrictions as well as penalties for exceeding of allowed exhaust gas emission. Therefore, alternative fuels and new bus drive systems might have an increasing role in the public passengers transport system [5-10].

The transportation system that will offer a high quality public transport service and comfort comparable to personal cars, and that will be close to the potential users, is needed [21]. Such the transportation system as an add-on to conventional transit service is in the focus of this paper. It consists of two integral parts and propositions to use:

1. An advanced city bus or minibus as an appropriate transport means (introduction of alternative fuels and technologies for public transport); and
2. From door to door transportation which will bring the transport service close to the users, parallel with an appropriate information and communication system which will enable passengers information and effective management.

Such the transport system should offer a "shuttle for everybody" in everyday use and be an effective means to clean the majority of cars off the roads and the cities [21]. That would be one of the most effective, the least expensive and the fastest for implementation way for contribution to direct and indirect fuel economy and accompanying results.

This paper will outline each of the components of proposed transportation system with focus on its first component, an advanced city bus with alternative drive system.

\section{ALTERNATIVE DRIVE SYSTEMS FOR PUBLIC PASSENGERS TRANSPORT}

Although city transport is dominated by private car use, from the point of view of sustainable mobility and costs/effectiveness the city buses should play an important role. Developing technology aiming towards increased fuel economy and decreased gas emissions, specifically carbon dioxide $\left(\mathrm{CO}_{2}\right)$ that will provoke increasing penalties, are the same for all road vehicles. There is a variety of alternative fuels and technologies for cars and buses that may be used for the benefit of fuel economy and gas emissions $[5,7]$.

In order of effectiveness and complexity (costs), the following possibility and alternatives may be implemented for both cars and city buses.

\subsection{High quality fuel, new vehicles and good maintenance}

Ultra-low-Sulphur diesel in combination with advanced emissions control technologies can substantially lower the harmful emissions from diesel vehicles $[13,14]$.

Classic new buses built for Organization for Economic Co-operation and Development (OECD) countries are far cleaner than many buses built in developing countries. Such buses built in developing countries that will use them, may be a lower cost alternative and help develop the vehicle manufacturing industries in each country. Improvements should begin with better engines [5-10]. New cars and high quality fuel complying 
with new emission standards reduces substantially emission and improve fuel economy [11]. As to the cars that participate in city (urban) transport in enormous quantities, moderate engine power (smaller cars) would be highly appreciated.

Many old cars and buses, specifically in developing countries, are not maintained properly, leading to high emissions and low fuel economy. Maintenance systems could be strengthened quite cheaply.

\subsection{Alternative drive system running on natural gas}

The gaseous fuels as compressed or liquefied natural gas (CNG or LNG) offer the possibility for clean buses and cars $[5,9,22,23]$. For optimal performance, engines designed to run on these fuels should be used rather than converted from diesel or gasoline engines $[22,24,25]$. CNG engine is a good alternative to diesel engine. CNG engines operate with a three-way catalytic converter and eliminate nitrogen oxides (NOx) problems while offering comparable efficiency.

As example, taking in mind the experience of leading manufacturers of buses, the mechanical engineers in domestics Production Company from Kragujevac city have successfully designed a prototype of fully low floor city bus with CNG drive, on the homologated chassis produced by MAZ factory, as shown in Fig.1 [5,6,9,22,23].

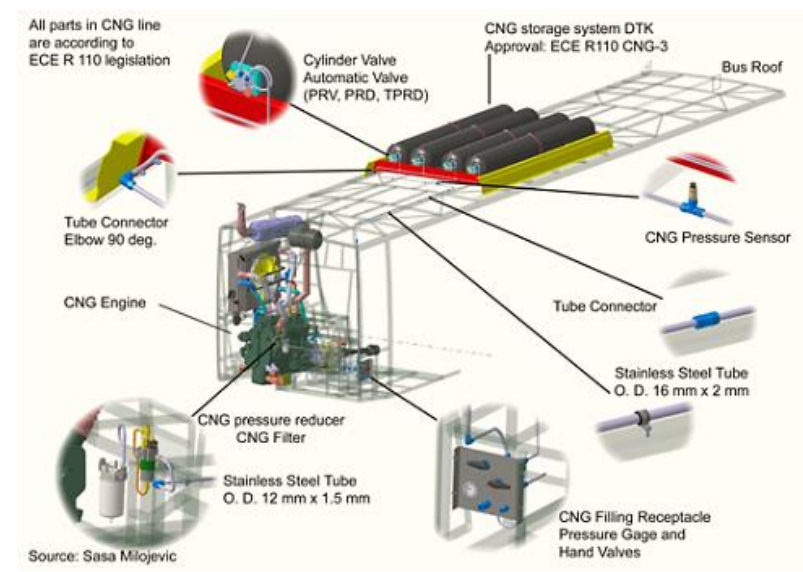

Fig. 1. Rack with aluminum cylinders for $C N G$ and position of mounting on the roof of bus

Generally, the viability of different fuels in different cities depends in part on fuel availability and fuel supply infrastructure. Installation of refuelling infrastructure can take time and will be costly, and bus companies must be trained in the handling and use of gaseous fuels.
The problem is also the lack of current market demand for CNG vehicles. Unfortunately, the CNG filling station network in Europe is still incomplete, and although potential remains on the north-south axis, the situation is far worse from east to west. All of this compounds the difficulty of bringing monovalent products optimized for CNG to the market.

Biofuels are a good alternative concerning gas emissions, but without subsidies their costs may be high. On the other hand, production of some of them is at the expense of food production.

We are analyzed also the possibilities for production of biogas from landfill and agricultural crops. By upgrading biogas to bio-methane we produce the high quality fuel for mobility systems causing lower exhaust emission specifically particulate matter, sulfur compounds, nonmethane hydrocarbons and nitrogen oxide, as well as smog and noise pollution in the atmosphere [26].

\subsection{Hybrid electric drive}

Hybrid-electric drive system is the most effective concerning fuel economy and along with it gas emission, specifically $\left(\mathrm{CO}_{2}\right)$ for both cars and city buses. This technology is complex, Fig. 2 and costly for investment in new buses and for operation. Thus it will be out of reach for many small transport service providers. But it is increasingly seen as part of the transition to fuel cells since it employs the same type of electricdrive system, and because this technology appears likely to be commercialised much sooner in city transport [27].

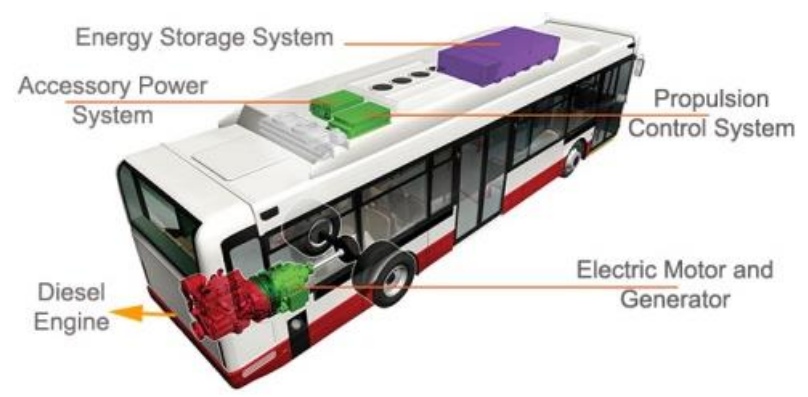

Fig. 2. City bus with integrated hybrid drive system

Hybrid electric vehicles (HEVs) are powered by an IC engine or other drive source that can run on conventional or alternative fuel in combination with an electric motor that uses energy stored in a battery. Because HEVs cannot plug in to off-board sources of electricity to charge the battery, one of 
solution is the vehicle uses regenerative braking and IC engine to charge.

HEVs can be designed as mild or full hybrids (in series or parallel configurations).

Mild hybrids (micro hybrids) use a battery and electric motor in combination with diesel engine and have integrated start-stop system usually, which shut off the IC engine when the vehicle stops (red traffic light or in stop-and-go traffic).

From the second side, there are full hybrids which have larger batteries and more powerful electric motors on the vehicle. Full hybrids can operate using electricity along, which is not the case with micro hybrids that helps diesel drive. These systems cost more compared to micro hybrids but provide better fuel economy benefits.

Regarding to the ways to combine the power from the electric motor and the IC engine to the drive wheels, on the market there are bus conceptions in form of parallel or serial hybrids.

As example, Scania has chosen a series hybrid design for city buses, which has no mechanical connection between engine and wheels, and use only the electric motor to drive wheels, Fig.3 [28].

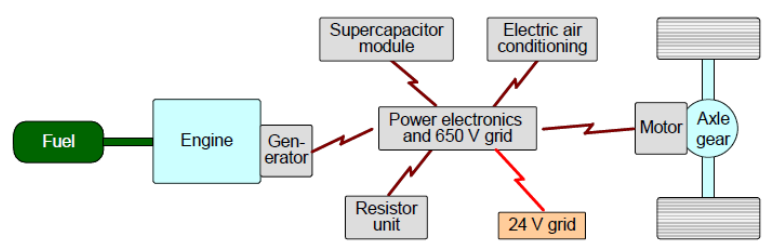

Fig. 3. Scania series hybrid powertrain for city bus of new generation

The series-hybrid powertrain permits the optimised operation of the IC engine when accelerating and this is important in urban conditions with a lot of stop-and-go driving due to the high degree of regenerative braking possible.

Series hybrid drive systems are used in plug-in and electric vehicles, too. Plug-in hybrid electric vehicles (PHEVs) have IC engine and an electric motor, which uses energy stored in batteries.

Parallel hybrid drive system connects the IC engine and the electric motor to the wheels through mechanical coupling. Electric motor and IC engine drive the wheels directly, Fig.4 [29,30].

With increased costs of operation of conventional buses and with the increased implementation of the hybrid electric technology, its costs may drop down quickly and as a result it may become cost/effective very soon.

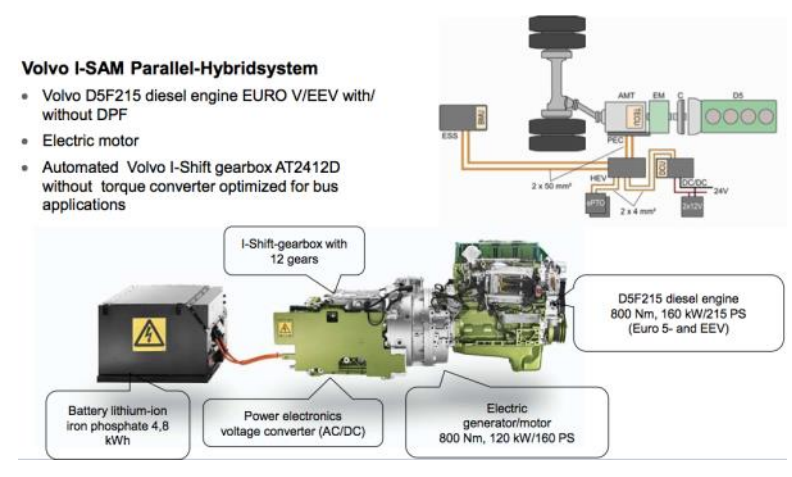

Fig. 4. Parallel hybrid drive system for city bus Volvo 7900 Hybrid

\subsection{Fuel cells (Hydrogen) drive system}

There are two possibilities to produce electricity on the vehicle with fuel cells: hydrogen stored or produced from other fuels by transformers. Fuel cell systems are also very complex, Fig.5 [27], and its implementation will be a big step. But once experience is gained with HEVs, and where possible with gaseous fuel vehicles and refuelling infrastructure, cities may be more prepared to deal with operating and maintaining fuel cell buses.

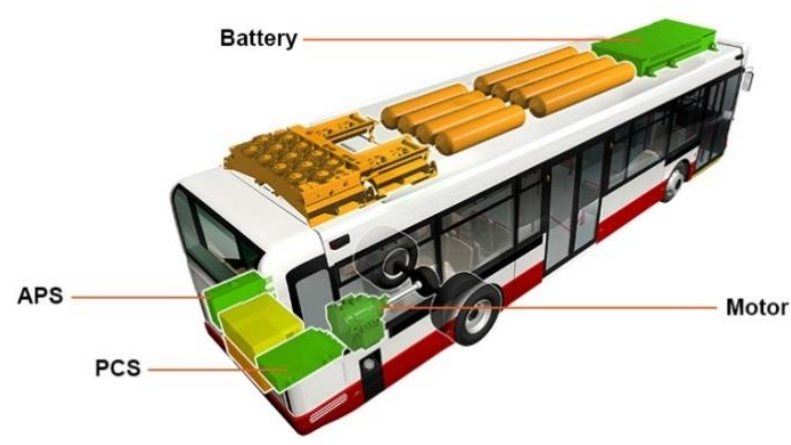

Fig. 5. Fuel cell technology implemented on the city bus

Using propulsion control system (PCS), electric power from battery and the hydrogen fuel cell engine is blended to provide power to the wheels and the electrified accessories. Regenerative braking also contributes to vehicle efficiency. The fuel cell engine uses hydrogen to generate all of the electricity needed for the bus.

If buses with on-board reforming are introduced, then the complexity level and importance of good maintenance practice will be even greater. Fleet operators, or urban transport service providers, are the closest to use this technology since they may have their own refuelling infrastructure. However its implementation will need time for competence building process. It is costly but totally clean and 
may be independent from fossil fuels if the hydrogen is produced from water and electricity. Thus electricity and hydrogen transport and storage systems will play the most important role for implementation of the fuel cells technology. Cars will wait until an appropriate infrastructure is built.

As contribution, it is proposed a prototype of fully low floor city bus with hydrogen drive system. The prototype bus is equipped with the original gas IC engine. Engine is designed to work only on compressed gaseous hydrogen (CGHy) [10]. On the Fig. 6 are shown parts of the installation for CGHy supply from bus roof mounted gas cylinders to the engine that is proposed to prototype version of HyS KG bus.

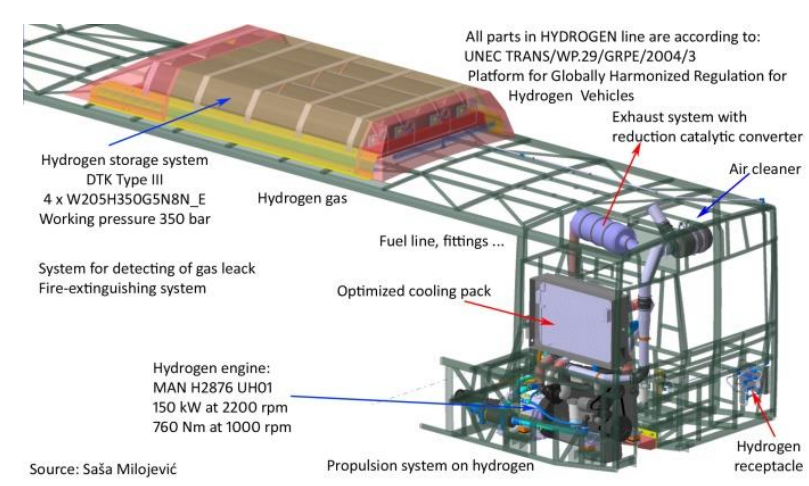

Fig. 6. Sketch of the CGHy fuel line equipment installed on the HyS KG bus

\subsection{Buses with electric drive system (E-buses)}

All electric vehicles (EVs) or battery electric vehicles (BEVs) use a battery pack to store the electrical energy that powers the motor. EVs batteries are charged by plugging the vehicle in to an electric power source. Although in the world most electricity production contributes to air pollution, EVs are categorized as zero-emission vehicles because they produce no direct exhaust emissions.

The introduction of buses with electric drive system (E-buses) or battery buses in the regular operation is a significant step in the development of public transport system in cities, Fig.7. Battery buses are equipped for charging with fixed pantographs at bus stops and in the Depot. Supercapacitors can be charged rapidly, reducing the time needed to prepare to resume operation. The concept of E-buses with the pantograph charging system on the termini completely meets the conditions of exploitation in terms of electricity supply, the daily autonomy, and the passengers' transport demands [31].

E-buses also eliminate infrastructure needed for a constant grid connection and allow routes to be modified without infrastructure changes compared to a Trolleybus.

Disadvantages of E-buses are less range, higher weight, and higher procurement costs. The reduced infrastructure for overhead lines is partially offset by the costs of the infrastructure to recharge the batteries. E-buses are used almost exclusively in urban areas rather than for long-haul transport. Urban transit features relatively short intervals between charging opportunities.

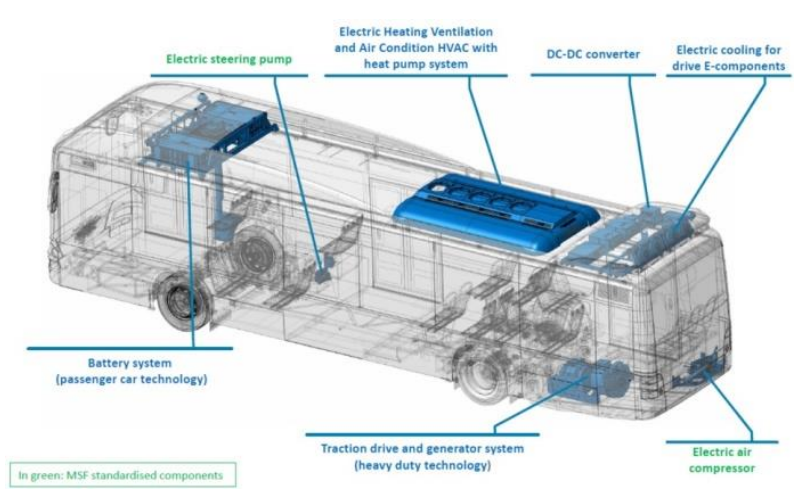

Fig. 7. Concept of E-bus or battery bus

Our proposition is the introduction of minibuses with electric drive system, instead of the existing on diesel, Fig.8. A fully electric minibus with a low floor and seating for up to 16 passengers has a range of up to 200 kilometres. This environmental friendly passenger vehicle is also incredibly economical to run with every kilometre costing significantly less compared with any equivalent diesel vehicle.

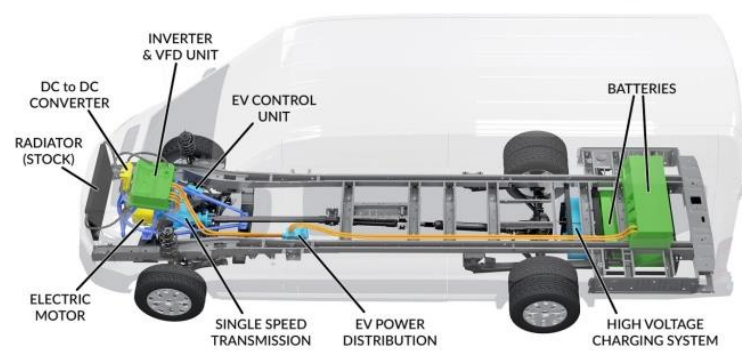

Fig. 8. Concept of electric minibus/minivan chassis

Generally, the electric buses bring with them a wide range of advantages, where the most important one is a reduction of air pollution levels. Switching to use electric buses should significantly improve the quality of air, and reduce morbidity and mortality due to air pollution.

Other advantages of the electric bus are: 
1. The cost of maintenance is about $25 \%$ lower than the maintenance cost of a diesel bus, since the electric motor doesn't need the same level of services the diesel engine needs;

2. Electric motor's energy losses are significantly lower than IC diesel engine's energy losses, so the cost per kilometer of electric bus travel is about a third of the cost of a diesel bus ride;

3. The electric bus is much quieter than a diesel bus, giving travelers a more pleasant experience and significantly reducing the environmental noise; and

4. The electric buses combine a regenerative braking system that generates electricity during the braking process.

Beside the positive side, there are also challenges:

1. As of today, the electric bus is significantly more expensive than a diesel bus, but the cost is expected to go down;

2. Adjustments must be made to the energy system according to the area in which the bus operates;

3. The conventional charging system limits the driving distance. Charging systems that enable long driving distance are still very expensive; and

4. Building a working plan (schedule) for an electric bus should consider a variety of parameters about the energy system.

\section{PUBLIC PASSENGERS TRANSPORT FROM DOOR TO DOOR WITH SUPPORT OF ADVANCED INFORMATION SYSTEM}

All alternatives from biofuels up to the hydrogen and electricity may be rapidly implemented in city transport. Congestion on the roads is one of the biggest causes for fuel wasting and pollution. It is mostly caused by personal cars used in city transport. Fuel economy is achievable in amazing quantity in city transport by various measures. One of them is relaxing congestions by offering car users high quality transport services with comfort comparable to cars [32-34].

As pointed out public passengers transport from door to door combined with Passengers Information System (PIS) is a transportation system that could tremendously decrease the number of cars in everyday traffic. Specifically, small passenger vehicles (minibuses) that may bring closer the transportation service to the users, increase the frequency, increase the speed and offer comfort comparable to individual cars may change the behaviour of many car users.

Similar transportation model, accompanied with an information and communication system, is implemented in many cities in various modalities in order to serve particular needs [21].

Proposed transportation system, exists more or less as a particular service for passengers' with specific needs, and has a little or no impact on nowadays urban transportation problems.

One may imagine a variety of transport service in order to bring the transport service as close to the potential users as possible. From the planned from door to door service where passengers are pick-up at the door and brought to the destination of each of them, up to the customized service that feed the big traffic lines, Fig.9, there is variety of different possibilities [33].

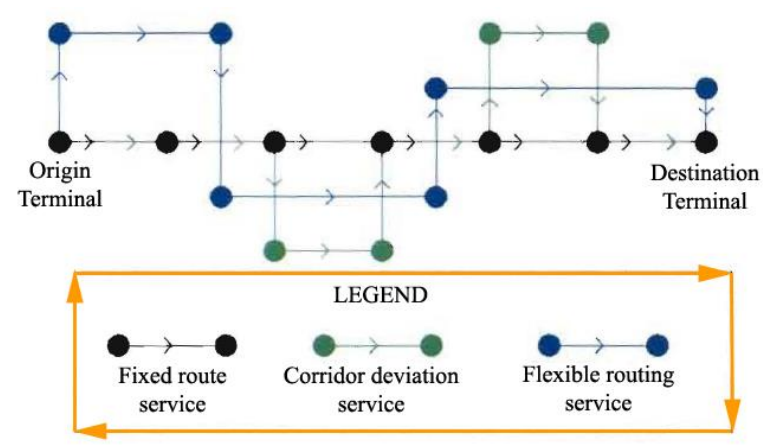

Fig. 9. Illustration of various service plans

In a basis fixed route, the bus or minibus with alternative drive system would operate in identical fashion to a conventional bus. It would follow a rigid schedule on a fixed route. In the corridor deviation service, the minibus can deviate to call at a few on-call locations, but must return to the fixed route path in order to call at all the normal fixed route stops. In the flexible routing mode, the normal route service end stops are not followed at all, and the bus or minibus is routed like a dial-abus to simply pick up and discharge passengers at the on-call locations based on calls for service from the passengers. Of course the bus would begin and end each trip at its end-point terminals.

Reliability is important, and to ensure that the buses must be controlled by an Advanced Vehicle Monitoring and Control System (AVMC System) that tracks the location of buses and provides twoway communication between the buses and the dispatcher so that any deviations can be dealt with expeditiously. In addition, there should be the PIS, 
which would include displays at all major stops indicating when the next few buses were to be expected (based on actual location, not schedule), and similar information would be available to others through telephone and personal computer source. Additional information resources, such as recommended routes in response to inquiries, could also be included. PIS and its relationship to vehicle operations and management are shown in Fig.10 [33].

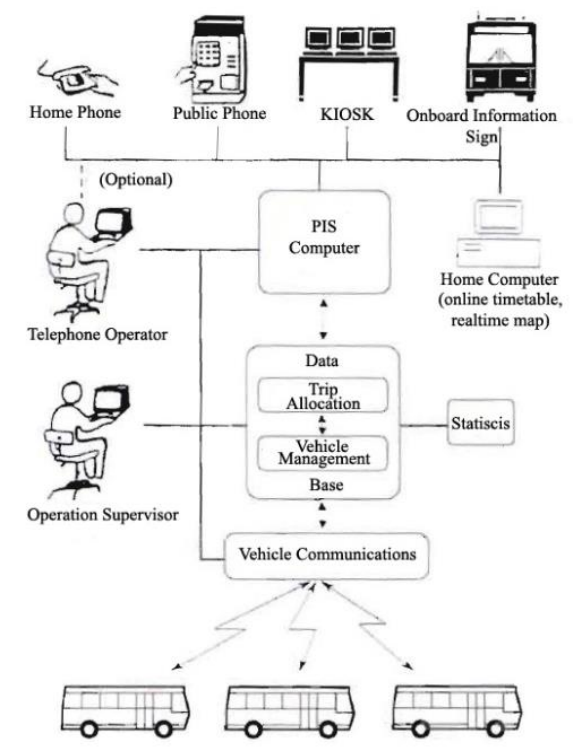

Fig. 10. PIS and its relationship to operations and dispatching

The combination of short headways and small vehicle size both make tailoring the service to do special needs of travellers on board a particular vehicle trip possible with far less disruption to the service than is possible with large vehicles.

With modest and prudent slack in the schedule should enable either accommodating a single wheelchair-bound traveller without divesting the schedule, a serious problem with larger high floor buses where the delays for boarding and alighting extend to many minutes. And the same slack can be used to accommodate modest route deviations on demand. Passengers calling for such a deviation in order to board can be told via whatever communication medium is used that the next bus will not be able to stop, but that the following one, expected at the specified time, will do so. And given that the intended market is primarily short trips, and routes would typically be short, the effect on schedule adherence should not be excessive. At times when the number of passengers is not sufficient to justify a fixed schedule and route, various types of on demand operations plans can be used. At one extreme, this would be like a dial-a-bus service, the minibus moving as needed to carry the passengers. At other times various combinations of a fixed route and route deviations could be used.

\section{EXPECTED BENEFITS}

Tremendous benefits may be achieved by decreasing the number of personal cars used for public transportation concerning fuel economy, gas emission, and business activities, by implementing the "from door to door" transport system as an add-on to the conventional transit traffic service. The example below gives evidence of it. Calculation is made based on 100000 vehicles on the roads in rush hours, which corresponds to a medium sized town. If, due to the implementation of the new transport service, in the first year the decrease of the number of cars were $5 \%$ and continues to decrease for additional $2 \%$ each year, the total decrease after the $3^{\text {rd }}$ year would be more than $20 \%$, and after 7 years the total decrease would be about $50 \%$, Table 1 .

Table 1. Decreasing the number of personal cars

\begin{tabular}{|c|c|c|c|c|}
\hline \multirow{2}{*}{ Control factors } & \multicolumn{4}{|c|}{ Year } \\
\cline { 2 - 5 } & 0 & 1 & 2 & 7 \\
\hline $\begin{array}{c}\text { Yearly decrease } \\
{[\%]}\end{array}$ & 0 & 5 & 7 & 17 \\
\hline Number of cars & 100000 & 95000 & 88350 & 43919 \\
\hline $\begin{array}{c}\text { Total decrease } \\
{[\%]}\end{array}$ & 0 & 5 & 12 & 56 \\
\hline
\end{tabular}

As example, if there were only 1000 low floor minibuses in a country offering high quality from door to door transport, they would transport at least 200000 passengers each day. Now, if $20 \%$ of them were former car users, 40000 cars would stay in the garage and about 240000 litters of fuel would be spared and not burned in cities. At yearly level it makes more than 2 million litters of fuel not burned in city centres and saved enormous quantity of exhaust emissions, specifically $\left(\mathrm{CO}_{2}\right)$.

\section{CONCLUSION}

The transport sector has seen fast growth in the number of vehicles and the consumption of transport-related energy. This has led to many problems including noise, pollution, congestion, accidents and deteriorating infrastructure.

Public passenger transport is an important alternative to the car. It plays a major role in the bigger cities where it carries (2.5-3) times as many 
people as private transport. Public passengers transport is also important for households who do not have a car.

Public passengers transport may contribute substantially to reduce the negative impact on the environment by application of alternative fuels. The main alternative fuels for drive systems in transport are electricity, hydrogen, and biofuels. Another way is introduction of flexible transport (from door to door, on demand, etc.). Each of these components must be well thought and thoroughly integrated in the system in order to answer to very demanding upcoming overall conditions and needs of the community.

Besides, it offers opportunity for development of new business activities for industrial and various services inside of new small and medium sized enterprises.

A pilot project implementing such a system in cities like Kragujevac, Kraljevo, Čačak, Novi Sad and Niš or Belgrade would represent a special experience, where mobility may be improved and the ambient may become much more pleasant, getting rid of personal cars on roads and streets. Specifically, also touristic organizations can use proposed passengers transportation systems in order to better meet the needs of tourists.

\section{ACKNOWLEDGMENT}

This paper is a result of the researches within the project (TR 35041), financed by the Ministry of Science and Techno-logical development of the Republic of Serbia.

\section{REFERENCES}

[1] B. Milosavljević, R. Pešić, D. Taranović, A. Davinić, S. Milojević, Measurements and modeling pollution from traffic in a street canyon: Assessing and ranking the influences. Thermal Science, 19 (6), 2015: 2093-2104.

https://doi.org/10.2298/TSCI150402111M

[2] N. Manić, I. Hot, D. Lukić, M. Pantić, Application of multicriteria optimization methods in the design of road embankments. Tehnički vjesnik, 23 (6), 2016: 1665-1672.

https://doi.org/10.17559/TV-20150325202514

[3] A. Asonja, E. Desnica, LJ. Radovanovic, Energy efficiency analysis of corn cob used as a fuel. Energy Sources, Part B: Economics, Planning, and Policy, 12 (1), 2017: 1-7.

https://doi.org/10.1080/15567249.2014.881931
[4] R. Pešić, S. Milojević, D. Taranović, M. Stanojević, Experiences related to inspection of Motor Vehicles running on Natural Gas in the Republic of Serbia, VII International Congress, Motor Vehicles \& Motors 2018, Ecology - Vehicle and Road Safety - Efficiency, $4^{\text {th }}$ October 2018, Kragujevac, Serbia, pp.245254.

[5] S. Milojević, R. Pešić, CNG buses for clean and economical city transport. Mobility \& Vehicle Mechanics (MVM), 37 (4), 2011: 57-71.

[6] S. Milojevic, R. Pesic, Theoretical and experimental analysis of a CNG cylinder rack connection to a bus roof. International Journal of Automotive Technology, 13 (3), 2012: 497-503.

https://doi.org/10.1007/s12239-012-0047-y

[7] S. Milojević, Reconstruction of existing city buses on diesel fuel for drive on Hydrogen. Applied Engineering Letters, 1 (1), 2016: 16-23.

[8] S. Milojević, D. Gročić, D. Dragojlović, CNG propulsion system for reducing noise of existing city buses. Journal of Applied Engineering Science, 14 (3), 2016: 377-382.

https://doi.org/10.5937/jaes14-10991

[9] S. Milojević, Sustainable application of natural gas as engine fuel in city buses - Benefit and restrictions. Journal of Applied Engineering Science, 15 (1), 2017: 81-88.

https://doi.org/10.5937/jaes15-12268

[10] S. Milojevic, Optimization of the Hydrogen System for City Busses with Respect to the Traffic Safety, 20 $0^{\text {th }}$ World Hydrogen Energy Conference (WHEC 2014), 15 ${ }^{\text {th }}$ June 2014, Gwangju, South Korea, pp.853-860.

[11] J. Schommers, H. Scheib, M. Hartweg, A. Bosler, Minimizing friction in combustion engines. MTZ Worldw, 74 (7-8), 2013: 28-35.

https://doi.org/10.1007/s38313-013-0072-x

[12] R. Pešić, S. Milojević, S. Veinović, Benefits and Challenges of Variable Compression Ratio at Diesel Engines. Thermal Science, 14 (4), 2010: 1063-1073.

https://doi.org/10.2298/TSCI1004063P

[13] R. Pesic, S. Milojevic, Efficiency and Ecological Characteristics of a VCR Diesel Engine. International Journal of Automotive Technology, 14(5), 2013: 675-681.

https://doi.org/10.1007/s12239-013-0073-4

[14] S. Milojević, Analyzing the Impact of Variable Compression Ratio on Combustion Process in Diesel Engines, (Mr Thesis), University of Kragujevac, Faculty of Mechanical Engineering, Kragujevac, Serbia, 2005. 
[15] S. Milojevic, R. Pesic, D. Taranovic, Tribological optimization of reciprocating machines according to improving performance. Journal of the Balkan Tribological Association, 21 (3), 2015: 690-699.

[16] B. Stojanović, S. Milojević, Characterization, Manufacturing and Application of Metal Matrix Composites, In: Wythers MC (ed) Advances in Materials Science Research, $30^{\text {th }}$ edn., Nova Science Publishers, New York, 2017, pp.83-133.

[17] S. Milojević, R. Pešić, D. Taranović, Tribological Principles of Constructing the Reciprocating Machines. Tribology in Industry, 37 (1), 2015: 13-19.

[18] S. Milojević, D. Džunić, D. Taranović, R. Pešić, S. Mitrović, Tribological Reinforcements for Cylinder Liner of Aluminum - Example Compressors for Brake Systems of Trucks and Buses, $15^{\text {th }}$ International Conference on Tribology (SERBIATRIB'17), 17 ${ }^{\text {th }}$ May 2017, Kragujevac, Serbia, pp.251-257.

[19] S. Milojević, R. Pešić, Determination of Combustion Process Model Parameters in Diesel Engine with Variable Compression Ratio, Journal of Combustion, 2018 (-), 2018: 1-11.

https://doi.org/10.1155/2018/5292837

[20] N. Z. Kontrec, G. V. Milovanović, S. R. Panić, H. Milošević, A Reliability-Based Approach to Nonrepairable Spare Part Forecasting in Aircraft Maintenance System, Mathematical Problems in Engineering, 2015 (-), 2015: 1-7.

https://doi.org/10.1155/2015/731437

[21] U. Leiss, U. Fischer, RECONNECT- Reducing Congestion by Introducing New Concepts of Transport, Final Report, European $4^{\text {th }}$ RTD Framework Programme.

[22] S. Milojević, R. Pešić, Logistics of Application Natural Gas on Buses, $10^{\text {th }}$ International Automotive Congress Automotive Engineering and Environment (CAR 2011), $3^{\text {rd }}$ November 2011, University of Pitesti, Romania.

[23] S. Milojević, R. Pešić, Benefit and Restrictions Related to the Application of Natural Gas as Engine Fuel for City Buses, $13^{\text {th }}$ International Conference on Clean Energy 2014 (ICCE-2014), $8^{\text {th }}$ June 2014, Istanbul, Turkey.

[24] P. Hofmann, T. Hofherr, G. Hoffman, J.F., Preuhs, Potential of CNG Direct Injection for Downsizing Engines, MTZ Worldw, 77 (7-8), 2016: 28-35

https://doi.org/10.1007/s38313-016-0074-6
[25] S. Streng, P. Wieske, M. Warth, J. Hall, Monovalent Natural Gas Combustion and Downsizing for Lowest $\mathrm{CO}_{2}$ Emissions. MTZ, 77, 2016: 16-22.

[26] S. Milojević, R. Pešić, Application of Biomethane in Motor Vehicles. Tractors and Power Machines, 19 (4), 2014: 16-25.

[27] BAE Systems, Advancing Electric Solutions, 2018.

http://www.hybridrive.com/pdf/bus/advancing el ectric solutions brochure.pdf. (Accessed 26.01.2018.).

[28] L. Overgaard, A. Folkesson, P. E. Nordstrom, Passenger-friendly hybrid bus concept, 2018. https://www.scania.com/group/en/wpcontent/uploads/sites/2/2015/09/P07501ENPassenger-friendly-hybrid-bus-concept tcm 10 163545 tcm40-813111.pdf (Accessed 26.01.2018).

[29] Volvo Bus, "Volvo 7900 Hybrid", 2018. http://www.volvobuses.co.uk/en-gb/ouroffering/buses/volvo-7900-hybrid.html (Accessed 03.02.2018).

[30] D. Stanojević, N. Lužanin, M. Vasić, N. Stanojević, M. Todorović, Contribution to the consideration of significance of hybrid buses implementation in city traffic companies. Mobility \& Vehicle Mechanics (MVM), 42 (3), 2016: 23-34.

[31] S. Mišanović, Z. Živanović, D. Savković, P. Krstić, S. Ivanov, S. Stević, Two-year successful exploitation of the electric buses in Belgrade, $7^{\text {th }}$ International Congress, Motor Vehicles \& Motors 2018, Ecology - Vehicle and Road Safety - Efficiency, $4^{\text {th }}$ October 2018, Kragujevac, Serbia, pp.487-492.

[32] B. Sarkan, T. Skrucany, S. Semanova, R. Madlenak, A. Kuranc, M. Sejkorova, J. Caban, Vehicle coast-down method as a tool for calculating total resistance for the purposes of type-approval fuel consumption. Scientific Journal of Silesian University of Technology. Series Transport, 98 (-), 2018: 161-172.

https://doi.org/10.20858/sjsutst.2018.98.15

[33] S. Milojević, R. Pešić, Challenges in City Transport - Alternative Fuels and Door to Door Model, $4^{\text {th }}$ International Conference Mechanical Engineering in XXI Century, $19^{\text {th }}$ April 2018, Niš, Serbia, pp.387-392.

[34] T. Skrucany, S. Semanova, M. Kendra, T. Figlus, J. Vrabel, Measuring mechanical resistances of a heavy good vehicle by costdown test. Advances in Science and Technology Research Journal, 12 (2), 2018: 214-221.

https://doi.org/10.12913/22998624/91889 